\title{
THE EFFECT OF GOOGLE SEARCH VOLUME INDEX ON UNDERPRICED IPOS AND DIVERGENCE OF OPINIONS
}

\author{
Megen Chivianti ${ }^{1}$, Sukmawati Sukamulja ${ }^{1^{*}}$ \\ ${ }^{1}$ Management, Business and Economics, Atma Jaya Yogyakarta University, Yogyakarta, 55281, \\ Indonesia
}

\begin{tabular}{|c|c|}
\hline ABSTRACT & ARTICLE INFO \\
\hline $\begin{array}{l}\text { Introduction/Main Objectives: The purpose of this paper is to examine } \\
\text { the effect of the Google Search Volume Index (GSVI), as the moderating } \\
\text { variable, on underpriced IPOs, as the independent variable, on the } \\
\text { divergence of opinions, as the dependent variable. Background } \\
\text { Problems: A divergence of opinions may arise when an error occurs } \\
\text { while estimating the right price due to the unavailability of information or } \\
\text { only having limited information. Before a company conducts an IPO, } \\
\text { potential investors will look for information about the company and each } \\
\text { one may interpret the data differently, which results in disagreements } \\
\text { between the investors. The investors' attention is a disagreement } \\
\text { mechanism. Research Methods: This study employs the regression } \\
\text { analysis of moderation variables with an absolute difference method } \\
\text { (ADM) on a sample of } 79 \text { Indonesian companies that conducted an IPO } \\
\text { between } 2015 \text { and } 2019 \text {. Finding/Results: This study discovered a } \\
\text { negative relationship between the initial return and market-adjusted } \\
\text { turnover without an interaction effect in the model. The investors' } \\
\text { attention reduces disagreements about underpriced IPOs in the } \\
\text { aftermarket. Conclusion: The result of this study found that investors' } \\
\text { attention reduces disagreements about underpriced IPOs proxied by the } \\
\text { initial return, because investors closely monitor other information } \\
\text { available on the Internet. }\end{array}$ & $\begin{array}{l}\text { Article information: } \\
\text { Received: April 29, } 2020 . \\
\text { Received in revised } \\
\text { version: July 28, } 2020 . \\
\text { Received in revised } \\
\text { version: September } 30, \\
\text { 2020. Accepted: } \\
\text { November 10, } 2020 .\end{array}$ \\
\hline
\end{tabular}

\footnotetext{
${ }^{1}$ Corresponding Author at Department of Management, Faculty of Business and Economics, Atma Jaya Yogyakarta University, Jalan Babarsari 43, Yogyakarta 55281, Indonesia.

E-mail address: megenchivianti@gmail.com (author\#1), sukmawati.sukamulya@uajy.ac.id (author\#2 \& correspondent author)
} 


\section{INTRODUCTION}

Indonesia is one of the countries that has entered the era of globalization (or the digital era). The growing era of globalization affects all aspects of people's lives, and especially their economic aspects. It makes the world's economy and trade easier, and opens up international markets to domestic products. Companies will confront many obstacles in implementing strategies to stay ahead of the competition. Companies will need to raise capital funding to expand their businesses.

Companies can utilize various forms of media to obtain funds and investment, for instance through the capital market. Private companies have the opportunity to become public companies and they can then obtain funds by selling securities or shares to the public, hereinafter referred to as, "Go Public." The shares are offered on the primary market, and this is called the initial public offering (IPO). Furthermore, securities that have been publicized will be traded on the aftermarket
(Isfaatun \& Hatta, 2010). By conducting an IPO, a company can obtain enormous amounts of funds at a relatively lower cost of funding. In addition, a public company can make a secondary offering in the future so that the company has unlimited access to funds.

In recent years Indonesia's capital market has growing rapidly. However, unlike some other countries that experienced negative growth in the number of companies that going public, such as Singapore. Singapore is already saturated capital market, not to much companies left to go public. The Otoritas Jasa Keuangan (OJK), along with the capital market regulator, are both optimistic that Indonesia's capital market will grow because the number of investors is less than $1 \%$ of the population, and it has not reached the saturation point. Based on the Ernst and Young Global IPO Trends Q3 2019 data, there were only 11 registered companies in Singapore on October 18, 2019. Concurrently, during Q3 2019, 41 companies held their IPOs in Indonesia (Alinea, 2019).

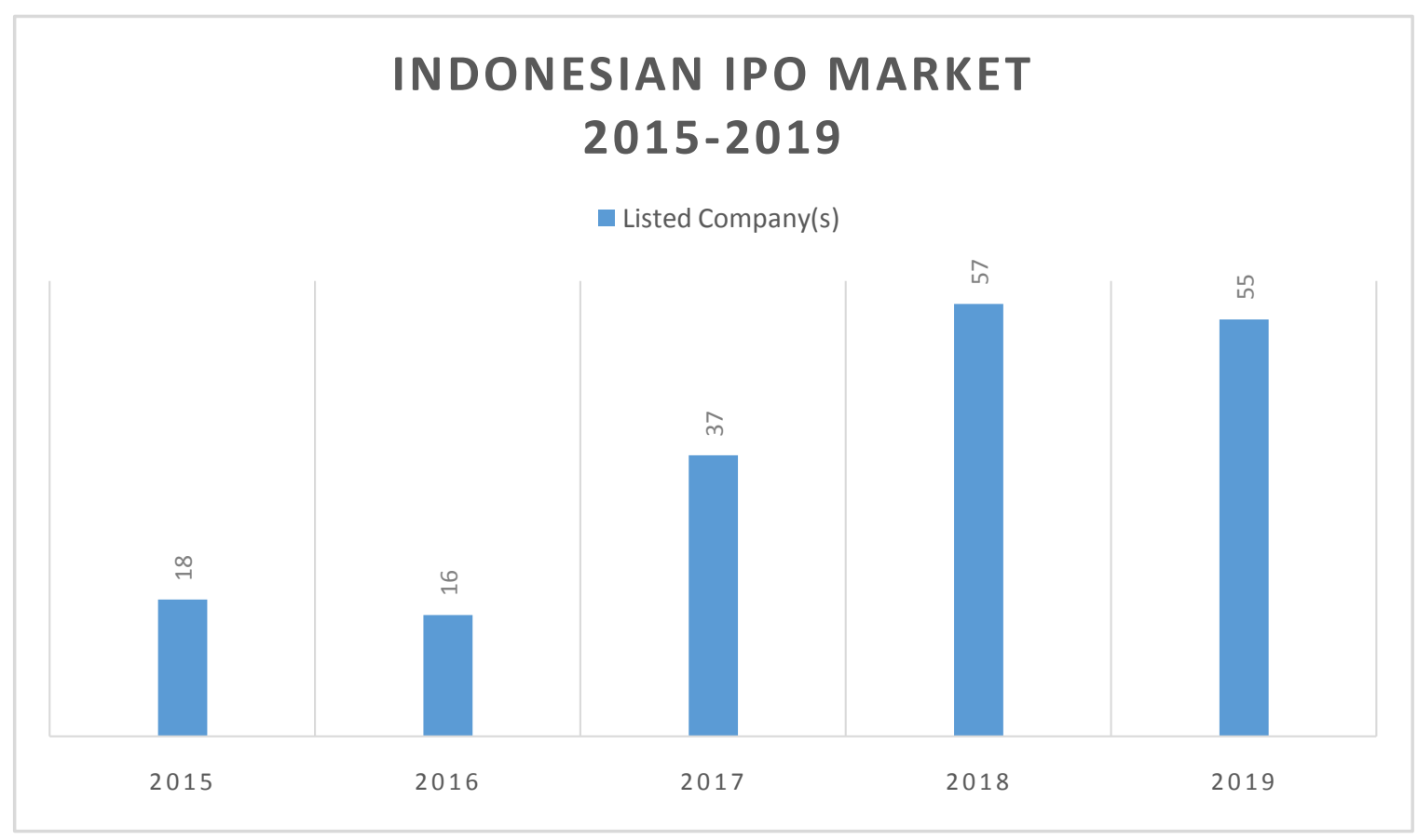

Source: Indonesia Stock Exchange

Figure 1.The growth of IPO companies on the Indonesia Stock Exchange from 2015 to 2019 
The growth in Indonesia's capital market proves it is increasingly needed as part of the government's way to foster the country's economic growth. The increase of IPO companies in Indonesia began in 2017, driven by conducive domestic and global economic conditions as well as a supportive monetary policy (such as lowinterest rates) that encouraged investors to divert investments from the money markets to the capital markets (Infovesta, 2017). The government, through the Indonesia Stock Exchange, launched a capital markets domestic campaign with the theme "Let's Saving Stock" (in Indonesian $=$ "Yuk Nabung Saham"). The campaign aimed to increase public awareness about investing in Indonesia's capital market. "Yuk Nabung Saham" encouraged the public, investors, and potential investors to invest regularly in the capital market. The number of Indonesian investors obtaining a Single Investor Identification (SID) number by the end of July 2018, as recorded by the Kustodian Sentral Efek Indonesia (KSEI), a self-regulatory organization, had reached 1,369,810 (Khairunizam \& Isbanah, 2019).

The investment decision-making of each investor will differ, being influenced by each investor's response to the opportunities and challenges of the ever-changing economic environment (Wijayanthi, 2015). According to Paramita et al. (2018), in a biased financial decision-making situation, individuals must equally include any psychological aspects that can distort irrational behavior. Investors have limited cognitive abilities for interpreting the information they receive, resulting in a difference of opinion between one investor and another (a divergence of opinions). The divergence of opinions arise due to the heterogeneity of an estimation of the value of assets between investors (Wang \& Liu, 2014). They can occur because some investors have an optimistic attitude regarding their investments, and it can emerge in an efficient or an inefficient market, assuming that investors' expectations vary, or are non-homogenous (Miller, 1977). Investors that become cognitively overloaded will only notice a portion of the information from the variety of publicly obtainable information, resulting in abnormal price and volume behavior (Narayanasamy et al., 2018). When the IPO's offering price is lower than the closing stock price on the first-day of trading, it is known as underpricing. Figure 2 presents the two separate assumptions underpinning the divergence of opinions and the link to attention. The link between attention and volume behavior generated from a divergence of opinions is unclear.

A divergence of opinions will arise when an error occurs in an estimation due to the unavailability of information or there only being limited information. Before a company conducts an IPO, potential investors will look for information about the company, and each one may interpret the data differently, which results in disagreements between the investors, so the investors' attention is a disagreement mechanism. Theoretically, it is stated that attention is a tool of disagreement that is likely to affect the relationship between company's share price. From a psychological standpoint, people tend to closely monitor information, particularly if it is easy to process (Narayanasamy et al., 2018). Investors will trade stocks they are familiar with. At the moment the information appears on the market, only the attention of the investors causes changes in the stock's price, indicating that the investors' attention is a necessary part of stock trading. Thus, investors' attention is the key to investors' decision-making (Merton, 1987). Da et al. (2011) introduced the Google Search Volume Index into their study of IPOs, as it was the best direct measure for precisely capturing the investors' attention. 


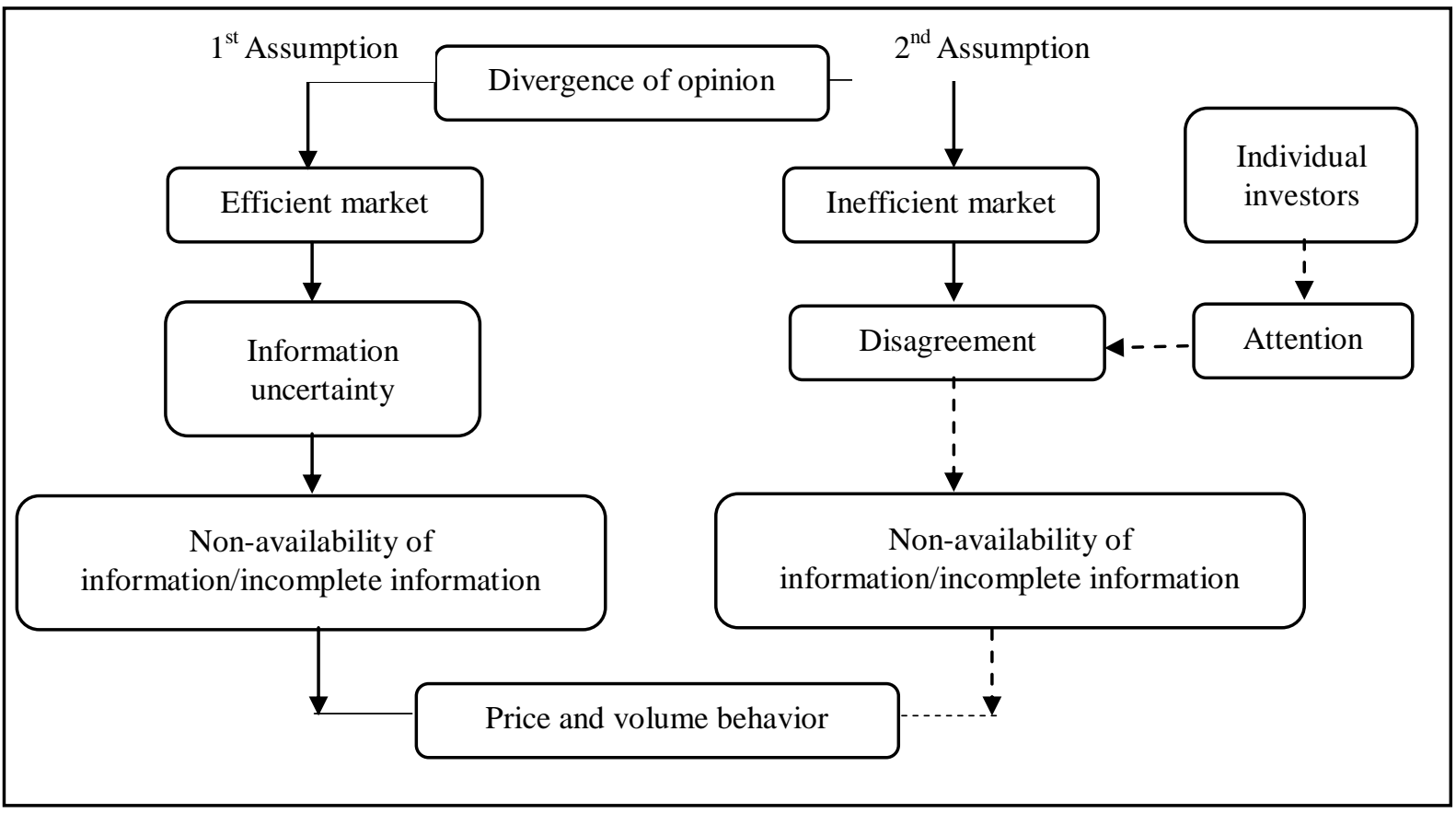

Source: Narayanasamy, Rashid, and Ibrahim (2018)

Figure 2. Presents two assumptions about the divergence of opinions (DOP) related to investors' attention

Narayanasamy et al. (2018) found a significant and positive relationship between underpriced IPOs and the divergence of opinions and suggested that investors' attention reduces disagreements about the quality of underpriced IPOs. Low \& Yong (2013) conducted research into IPO underpricing and the offer size in relation to investors' heterogeneous beliefs. The results of their study indicated the offer price of the IPO negatively affected the investors' heterogeneous beliefs. The broad disagreement between IPO investors reflects a strong disagreement in the investors' assessment of the actual aftermarket price of the IPO. Yüksel \& Yüksel (2006) conducted research into the relationship between the underpricing of IPOs and the trading volume. The result indicated there was no significant relationship between stock retention and underpricing. A company does not use underpricing as a tool to reduce the liquidity caused by higher stock retention. The results of that study also showed a significant positive relationship between underpricing and trading volumes, in the short term.
Motivated by underpriced IPOs in the Indonesian IPO market, the average IPO in Indonesia was underpriced by $91.27 \%$ during 2018. The underpriced by $91.27 \%$ during 2018 is the highest recorded compared to the IPO activity in the last five years. This study provides knowledge about behavioral finance, linking individual investors' attention and disagreements to address the uncertainty about the IPO market's volume and price behavior. This research aims to find the relationship between the underpricing phenomenon in the market for an initial public offering (IPO) with the divergence of opinions moderated by investor attention through the Google Search Volume Index.

The following sections presents the literature review and hypothesis development, research method, analysis and the last draws conclusions based on the result. The first half of this article discusses the background and framework of the divergence of opinions and individual investors' attention. The second half of the paper provides the empirical results. 


\section{LITERATURE REVIEW}

\section{Behavioral Finance}

Studies about the psychological and sociological factors that explain emotional processes, the understanding of investors' reasoning patterns, and what affects the financial decision-making processes of individuals, groups, and entities are all termed behavioral finance (Ricciardi \& Simon, 2015). Pompian (2006) divided behavioral finance into two types: micro-behavioral finance examines the behavior or bias of individual investors in the classical economic theory and macro-behavioral finance describes anomalies in the efficient market hypothesis (EMH) that can be explained by behavioral models.

In determining investment decisions, investors encounter several considerations. These considerations can affect the investors' actions in making an investment decision. The actions that an investor takes are sometimes rational, but there are also irrational acts. The rational attitude of investors is the type of thinking that is based on reason and can be proved by the existing data and facts. Irrational attitudes are profoundly influenced by the investor's psychological factors. The involvement of emotions, passions, traits, and the various things inherent in human beings that often cause humans to act irrationally when making decisions (Pradhana, 2018). A biased investor will ignore the existing information and facts, and reach their own conclusion, and then convince themselves that their choice is the correct one. According to Pompian (2006), the bias is divided into two categories: cognitive bias and emotional bias. The deviation in the process of understanding, processing, and decision-making based on information or facts is called cognitive bias. Emotional bias is a deviation because it emphasizes feelings and a spontaneous reaction to the facts.

\section{Market Behavior}

Economic behavior will affect the economic market. Market results reflect individual collective decisions. The market may not be rational because of the collective behavior of the market players. The efficient market hypothesis (EMH) relies on the notion that investors behave rationally and their behavior bias is so diverse that irrational behavior will only have a slight effect on the market. If an asset is offered at the wrong price, so that the market price diverges from its intrinsic value, knowledgeable investors will take advantage of the opportunity. According to Fama (1970), in the securities market that are many investors with extensive knowledge, the investments will be priced accordingly and will reflect all the information available. There are three forms of the efficient market hypothesis (EMH): a strong-form EMH, a semi-strong-form EMH, and a weak-form EMH. Investing in an inefficient market causes the value of assets to rise, leading to more profits and investments. Market inefficiencies can persist due to economic and cultural factors, such as lowering interest rates and increasing the use of debt financing, new technology, decreasing government regulation or supervision, and demographic factors (Siegel \& Yacht, 2009).

\section{Divergence of Opinions (DOP) and IPO}

DOP will arise when there is an error in the estimation due to the limited information or the unavailability of information (Goetzmann \& Massa, 2005). The assumption of a disagreement is to support the existence of the divergence of opinions about inefficient markets that are caused by a lack of investor knowledge and the ability to interpret information correctly, although all the investors have the same set of information (Hong \& Stein, 2007). The investors' disagreement has a major influence on asset prices and trading volumes. In the event of 
the disclosure of information to the public, such as the announcement of a company's profits, the investors will revise their decisions, which will impact on the trading volume (Giannini et al., 2019). One phenomenon that is inherent with an IPO is underpricing. Underpricing occurs when the stock price in the primary market is lower compared to the aftermarket. The positive difference between the stock price in the aftermarket and the primary market at the time of the IPO is called an initial return. Rock (1986) said that the underpricing of an IPO is required to compensate the investors who have no information (uninformed investors) compare to the informed investors.

\section{Attention and IPO}

From a psychological standpoint, individuals tend to closely follow information that is easier to process, and it has been stated that attention is a tool of disagreement that most likely affects the relationship between volume and price changes. Humans find it difficult to capture all the events that occur in the market. The need to find extensive information in an extremely brief time urges investors to use the stock's price changes. Therefore, when making investment decisions, investors closely monitor the information gathered from the market's price (Cajueiro et al., 2009; Peng \& Xiong, 2006). The Google Search Volume Index is the best direct method for attracting an investor's attention (Drake et al., 2012). There are several reasons to use the Google Search Volume Index (GSVI) for this. First, Google is the biggest source for search queries around the world. Therefore, search volumes reported by Google tend to represent the general population's search behavior. Second, a search is a measure of attention that is revealed directly, if someone searches for certain shares using Google then other people also start to pay attention to the stock. The GSVI is a measure of the search volume indexed and normalized for selected search terms provided by Google Trends. Google Trends provides time-series data, to the time and location specified by the user, by indicating the search results on a scale of 0 (there is not enough data) to 100 (the peak popularity). The number represents a search interest relative to the highest point on the chart for the given region and time.

\section{Hypothesis Development}

The concept of uncertainty suggests that investor expectations will differ because uncertainty leads to disagreement and, as predicted by many researchers, investor disagreement causes high trading volumes. The model of the theoretical trading volume by Karpoff (1986) stated that an increase in the trading volume may indicate that investors have conflicting interpretations of the information, or have identical interpretations but now have different expectations than before. The model suggests that trading volumes are a good proxy for disagreement among investors. Barber \& Odean (2006) emphasized to the quality of stocks that experience high abnormal trading volumes and extreme one-day stock returns. Attention-driven purchases arise from the difficulties encountered by investors when searching for the numerous stocks they may buy. Da et al. (2011) altered investors' attention by introducing the Google Search Volume Index as the best direct method to search for and find stocks. Narayanasamy et al. (2018) found that the investors' attention moderates the relationship between the underpricing phenomena in the IPO market and the divergence of opinion. Based on this explanation, the hypothesis that was proposed by this study is as follows:

Ha: Investors' attention moderates the relationship between the phenomenon of underpricing in the IPO market and the divergence of opinions. 


\section{METHOD, DATA, AND ANALYSIS}

\section{Sample and Data}

This study used secondary data because the data for this research were drawn from credible sources such as the website of the Indonesia Stock Exchange, Google Trends and IDN Financials' website. Data were obtained from stock market activity reports, and reports on the ownership of the securities of companies conducting IPOs listed on the Indonesia Stock Exchange (IDX) for the first time from 2015 to 2019, however companies that were re-listed on the Indonesia Stock Exchange (IDX) were not included. We choose the period from 2015 to 2019 because we needed at least five years worth of data for the analysis, and the most recent data that was available came from 2019. So from 2019 going five years backwards, we needed to collect data from 2015 onwards. Moreover, 2015 was the year of Ayo Menabung Saham campaign started. Re-listed companies were not included because the study is about the initial public offering of a company's stock. During the period from 2015 to 2019 , there were 183 companies conducting IPOs, 79 of them fulfilled the criteria of the data selection procedure in this study (see Table 1).

\section{Measures}

The phenomenon of underpricing that exists on the initial public offering (IPO) market was the independent variable in this study. The underpricing phenomenon in this study was measured using the initial returns, adapted from Narayanassamy et al. (2018). The initial return (PCC) is defined as the percentage price change of the first-day closing price $\left(P_{i}\right)$ from the IPOs offering price $\left(P_{0}\right)$, which is evaluated as follows:

$$
P C C_{i}=\left(\frac{P_{i}}{P_{0}}\right)-1
$$

The divergence of opinions, proxied by the market-adjusted turnover, adapted from Garfinkel (2009), were the dependent variable in this study. The market-adjusted turnover was obtained by subtracting the total volume on the first day of trading $\left(V_{i} / O U T_{i, t}\right)$ denominated by the number of outstanding shares from the market turnover $\left(V_{m, t} / O U T_{m, t}\right)$ for share issue $i$ at time $t=1$ :

$A b T O_{i, t}=\frac{V_{i, t}}{O U T_{i, t}}-\frac{V_{m, t}}{O U T_{m, t}}$

The investors' attention, which was measured using the Google Search Volume Index was the moderating variable in this study. The measure was adapted from (Oliveira, 2019), proxied by the search volume index. The search volume index $\left(\mathrm{SVI}_{\mathrm{i}, \mathrm{t}}\right)$ is a measure of the natural logarithms of Google's search volume indexed for share issue $i\left(\mathrm{GSVI}_{\mathrm{i}, \mathrm{t}}\right)$ and normalized to search for the terms provided by Google Trends. The assessor has between 0 to 100 , relative to the selected period:

Table 1. Data Selection Procedure

\begin{tabular}{lrrrrrc}
\hline Criteria & $\mathbf{2 0 1 5}$ & $\mathbf{2 0 1 6}$ & $\mathbf{2 0 1 7}$ & $\mathbf{2 0 1 8}$ & $\mathbf{2 0 1 9}$ & Total \\
\hline 1. IPO company in 2015 to 2019 & 18 & 16 & 37 & 57 & 55 & 183 \\
2. Relisted company & 2 & 1 & 0 & 0 & 0 & $(3)$ \\
3. Company without Google Search Volume Index data & 1 & 0 & 4 & 2 & 1 & $(8)$ \\
4. Company with negative abnormal turnover & 1 & 0 & 12 & 34 & 34 & $(81)$ \\
5. Company with initial return (IR) $\leq 0$ & 1 & 1 & 4 & 2 & 4 & $(12)$ \\
\hline Total sample & & & & & & 79
\end{tabular}

Source: Data Processed 


$$
S V I_{i, t}=\ln \left(G S V I_{i, t}\right)
$$

This research included one control variable that was established by prior studies to have a significant effect on the trading volume (Narayanasamy et al., 2018). In this study, the control variable used was firm size. The size of the company in this study was measured using market capitalization (KP), which was obtained by multiplying the market price $\left(\mathrm{P}_{\mathrm{s}}\right)$ by the outstanding shares $\left(\mathrm{S}_{\mathrm{s}}\right)$. According to Gujarati et al. (2018), because market capitalization is worth billions of rupiah, this can be simplified by transforming it into natural logarithms (ln), which were evaluated as follows:

$$
K P=\ln \left(P_{s} \times S_{s}\right)
$$

\section{Research Framework \& Method}

This research is an empirical study, so theories, hypotheses, and facts are needed. A hypothesis was used to predict the phenomena that occurred in this study. In summary, the research framework is illustrated in Figure 3 below.

This research used the absolute difference method. The regression analysis of a moderation variable by the absolute difference method is performed by redefining the absolute difference of a standardized independent variable with variables hypothesized to be standardized moderation variables (Ghozali, 2013). The absolute difference method was chosen because if the moderation variable is analyzed using the moderated regression analysis (MRA), there is a tendency for high multicollinearity between the independent variables to occur, in another sense, it would violate the classical assumptions in the ordinary least square (OLS) regression.

The following model was applied to test the investors' attention, as the moderating variable on the relationship between the phenomenon of underpricing in the IPO market and a divergence of opinions.

$$
\begin{aligned}
& A b T O_{i}=\alpha+\beta_{1} Z P C C i+\beta_{2} Z S V_{i}+ \\
& \quad \beta_{3} A B S(Z P C C-Z S V I)_{i}+\beta_{4} Z K P_{i}+\varepsilon_{i}
\end{aligned}
$$

$\mathrm{AbTO}_{\mathrm{i}}$ was the market adjusted turnover on the first day of trading for share issue i; $\mathrm{ZPCC}_{\mathrm{i}}$ was the standardized initial return on the first day of trading for share issue $\mathrm{I}$; $\mathrm{ZSVI}_{\mathrm{i}}$ was the standardized search volume index; ABS (ZPCC - ZSVI) $)_{i}$ was the absolute value of the difference between ZPCC and ZSVI (interaction terms); $\mathrm{ZKP}_{\mathrm{i}}$ was the standardized market capitalization; and $\varepsilon_{i}$ was an error term.

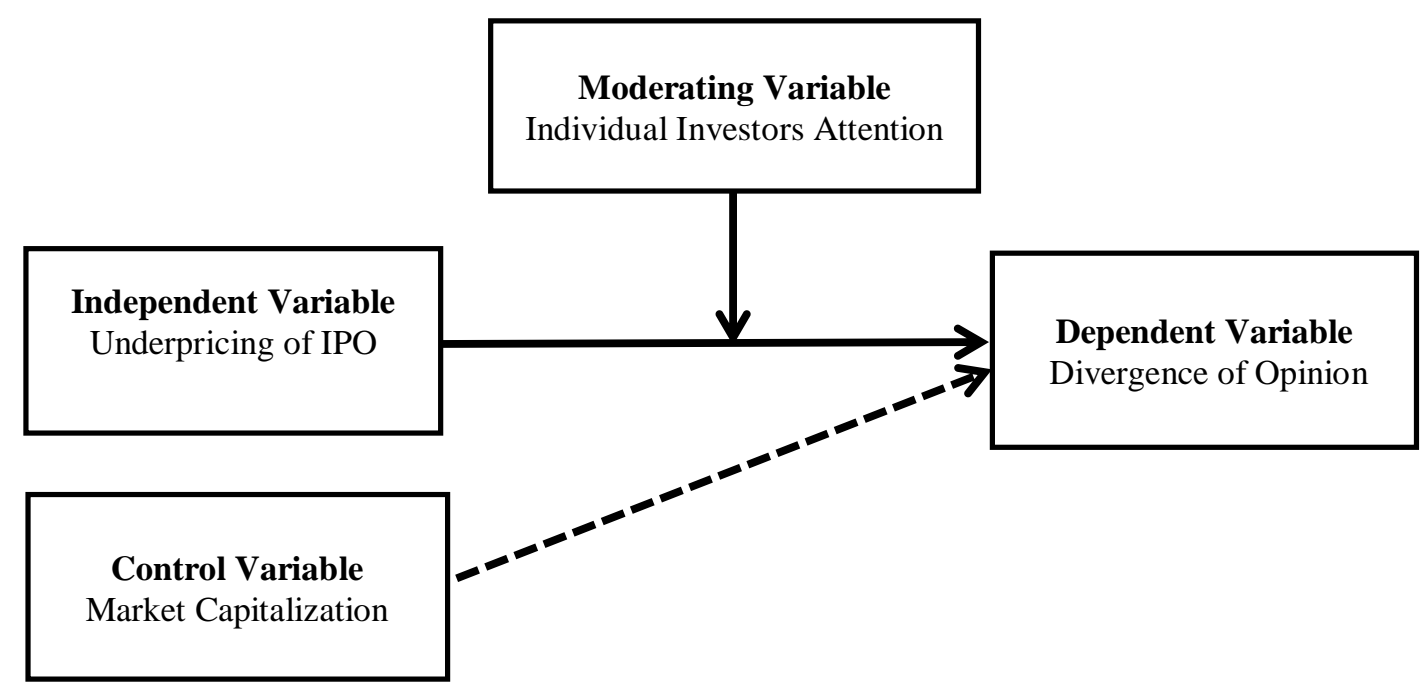

Figure 3. Research Framework 


\section{RESULT AND DISCUSSION}

\section{Descriptive Statistics}

This section explains the descriptive statistics. They are presented in Table 2 below. The results of the descriptive statistics' table show the data that have been transformed. Transformation was performed because the data being used were not normally distributed. The natural logarithms (Ln) transformation was carried out on all the research variables.

The descriptive statistics shown in Table 2 indicate that the variable divergence of opinions (AbTO) had a lowest value of -7.418 , a highest value of -0.089 , an average value of -3.844 , and a standard deviation of 1.593 . The underpricing phenomenon variable in the IPO market (PCC) had a lowest value of -5.403 , a highest value of 0.356 , an average value of -1.566 , and a standard deviation of 1.275. The variable investors' attention (SVI) had a lowest value of 1.298, a highest value of 1.527 , an average value of 1.485 , and a standard deviation of 0.060 . The market capitalization (KP) variable had a lowest value of 3.179 , a highest value of 3.428 , an average value of 3.303 , and a standard deviation of 0.053 .

\section{Hypothesis Testing and Discussion}

The testing of the hypothesis began by evaluating the suitability of the model, and the value of $p$. The results had already meet the criteria.

Table 2. Descriptive Statistics

\begin{tabular}{lcccc}
\hline \multicolumn{1}{c}{ Variables } & Minimum & Maximum & Mean & Std. Deviation \\
\hline Ln_AbTO & -7.418 & -0.089 & -3.844 & 1.593 \\
Ln_PCC & -5.403 & -0.356 & -1.566 & 1.275 \\
Ln_SVI & 1.298 & 1.527 & 1.485 & 0.060 \\
Ln_KP & 3.179 & 3.428 & 3.303 & 0.053
\end{tabular}

Notes: $n=79$ fixed price IPOs. Ln_AbTO denotes the natural logarithms of market adjusted turnover. Ln_PCC denotes the natural logarithms of the deviation of offer price from closing price at first day of trade scaled by offer price. Ln_SVI denotes the natural logarithms of attention captured by Google Search Volume Index. Ln_KP denotes the natural logarithms of market capitalization

Source: Data Processed

Table 3. Regression Analysis Results

\begin{tabular}{lccccc}
\hline \multirow{2}{*}{ Model } & \multicolumn{2}{c}{ Unstandardized Coefficients } & Standardized Coefficients & $t$ & Sig. \\
\cline { 2 - 6 } & B & Std. Error & Beta & & \\
\hline (Constant) & -3.349 & 0.315 & & -10.635 & 0.000 \\
Z(Ln_PCC) & -0.823 & 0.216 & -0.517 & -3.816 & 0.000 \\
1 Z(Ln_SVI) & -0.521 & 0.227 & -0.327 & -2.296 & 0.024 \\
Z(Ln_KP) & -0.545 & 0.178 & -0.342 & -3.055 & 0.003 \\
AbsPCC_SVI & -0.476 & 0.258 & -0.294 & -1.842 & 0.069 \\
R $^{2}$ & & & & & 0.215 \\
Adjusted R & & & & & 0.173 \\
F-Value & & & & & 0.001 \\
\hline
\end{tabular}

Notes: $n=79$ fixed price IPOs. Z(Ln_PCC) is the main independent variable denotes the standardize of the initial return (proxy underpricing). Z(Ln_SVI) is categorical moderator which captures investors' attention. $\mathrm{Z}\left(\mathrm{Ln} \_\mathrm{KP}\right)$ is control variables (proxy market capitalization). AbsPCC_SVI is the moderating effect. The variance inflation test factor (VIF) of the regression model confirms that VIF value of all the independent variables are far below the cut-off point 10 (Ghozali, 2013). Based on the F-test, it is safe to conclude that the model is a good fit. 
From the test results in the table above we get the following regression equation (based on formula number 5)

\section{Interpret the Statistical Output}

$$
\begin{gathered}
A b T O=-3.349-0.823 Z P C C-0.521 Z S V I- \\
0.545 Z K P-0.476 A B S(Z P C C-Z S V I)+\varepsilon i
\end{gathered}
$$

The underpricing phenomenon variable on the IPO market had a significance value of 0.000 , which was smaller than the $1 \%$ significance level, which meant that there was a significant relationship between the PCC and AbTO. The coefficient value $(\beta)$ of -0.823 indicated that the PCC had a negative effect on AbTO. The market capitalization variable, as a control variable, had a significance value of 0.003 , which was smaller than the $1 \%$ significance level, which meant that there was a significant relationship between KP and AbTO. The coefficient value $(\beta)$ of -0.545 indicated that KP had a negative effect on AbTO.

The moderator variable in this study was the investors' attention. In the regression model in this study, investors' attention was used as an independent variable and the moderator variable was the relationship between the phenomenon of underpricing in the IPO market and the divergence of opinions. The investors' attention variable, as an independent variable, had a significance value of 0.024 , which was smaller than the 5\% significance level, which meant that there was a significant relationship between SVI and AbTO. The coefficient value $(\beta)$ of -0.521 indicated that SVI had a negative effect on AbTO.

The variable of the investors' attention, as the moderator variable, was the relationship between PCC and AbTO, and had a significance value of 0.069 , which was greater than the $5 \%$ significance level. Therefore, the researchers used a significant level of $10 \%$ or 0.1 , so that the significance value was smaller than the $10 \%$ significance level, which meant that the investors' attention significantly moderated the relationship of PCC and AbTO. The coefficient value $(\beta)$ of -0.476 indicated that investors' attention reduced disagreement between the phenomenon of underpricing in the IPO market and the divergence of opinions about the aftermarket for IPOs.

\section{Hypothesis Testing}

The hypothesis testing results in this study stated that the phenomenon of underpricing in the initial public offering (IPO) market had a significant and negative impact on the divergence of opinions. This indicated that when the underpricing for the first stock offering (IPO), as measured by the initial return (IR), was higher it caused a divergence of opinions or disagreement between the potential investors, as measured by the turnover of the trading volume of the stock using the market adjusted turnover method, so the model will be lower, and vice versa. The research results of Bayley et al. (2006) and Low and Yong (2013), showed that there was a negative relationship between the initial return (IR) because of the abnormal stock trading volume. This meant that the divergence of opinions, which were proxied by stock turnover, were smaller because investors were optimistic about their opinion that stocks with a high return were the stocks to purchase. Investors who were outside the market still had the desire to enter the market, because the stock price on the first day of trading had increased, and they decided to enter the market when the stock price indicated signs of declining.

However, the results of this study supported the research of Narayanasamy et al. (2018) which showed that the investors' attention moderated the relationship between the underpricing phenomenon in the IPO market and the 
divergence of opinions. The investors' attention, as the moderator, weakened the relationship between the underpricing phenomenon in the initial public offering (IPO) market and the divergence of opinions at the $10 \%$ significance level. These results proved that the investors' attention reduced disagreements between the phenomenon of underpricing in the IPO market and the divergence of opinions. This suggests that when people search for more information on shares through online sources, they tend to pay attention to more information than just the information expressed by the initial price changes.

\section{CONCLUSION AND SUGGESTION}

This study found a negative relationship between the underpricing phenomenon in the initial public offering (IPO) market and the divergence of opinions. When an interaction effect was added, it showed that the individual investors' attention toward information gathered from online sources reduced the disagreement about the underpriced IPOs. This study shows that investors make their buying decisions by searching for other information on the Internet or other online sources. It distracts investors' attention from underpricing on the IPO market, causing fewer disagreements about the value of the IPO. Therefore, when investors closely monitor the other information disclosed by companies that conduct IPOs, instead of the market price, this can stop the existence of DOP in the aftermarket and at the same time reduce disagreements.

Researchers realize there is nonetheless a limitation in this study. The limitation lies in the keywords used in the search for investors' attention data on Google Trends. Keywords in the form of a full company name are not very effective because search engine users prefer searching for something written using short words.

\section{REFERENCE}

Alinea. (2019). OJK: pasar modal Indonesia tumbuh pesat dari negara lain. Retrieved from https://www.alinea.id/bisnis/ojk-pasarmodal-indonesia-tumbuh-pesat-dari-negaralain-b1Xoz9o4h

Barber, B., \& Odean, T. (2006). All that glitters: the effect of attention and news on the buying behavior of individual and institutional investors. Review of Financial Studies, $\quad 21(2), \quad$ 785-818. https://doi.org/10.2139/ssrn.460660

Bayley, L., Lee, P. J., \& Walter, T. (2006). IPO flipping in Australia: cross-sectional explanations. Pacific-Basin Finance Journal, 14(4), 327-348.

Cajueiro, D. O., Gogas, P., \& Tabak, B. M. (2009). Does financial market liberalization increase the degree of market efficiency? The case of the Athens stock exchange. International Review of Financial Analysis, 18(1-2), 50-57. https://doi.org/10.1016/j.irfa.2008.11.004

Da, Z., Engelberg, J., \& Gao, P. (2011). In search of attention. The Journal of Finance, 66(5), 1461-1499. https://doi.org/10.2139/ssrn.1364209

Drake, M. S., Roulstone, D. T., \& Thornock, J. R. (2012). Investor information demand: evidence from Google searches around earnings announcements. Journal of Accounting Research, 50(4), 1001-1040. https://doi.org/10.1111/j.1475679X.2012.00443.X

Fama, E. F. (1970). Efficient capital markets: a review of theory and empirical work. The Journal of Finance, 25(2), 383-417. https://doi.org/10.1684/bdc.2014.1986

Garfinkel, J. A. (2009). Measuring investors' opinion divergence. Journal of Accounting Research, 47(5), 1317-1348. https://doi.org/10.2139/ssrn.471301

Ghozali, I. (2013). Aplikasi Analisis Multivariate Dengan Program IBM SPSS 21 Update PLS Regresi. Semarang: Badan Penerbit Universitas Diponegoro. Information Technology, 2(2). 
Giannini, R., Irvine, P., \& Shu, T. (2019). The convergence and divergence of investors' opinions around earnings news: evidence from a social network. Journal of Financial Markets, 42(C), 94-120.

https://doi.org/10.1016/j.finmar.2018.12.003

Goetzmann, W. N., \& Massa, M. (2005). Dispersion of opinion and stock returns. Journal of Financial Markets, 8(3), 324349.https://doi.org/10.1016/j.finmar.2005.04 .002

Gujarati, D. N., Porter, D.C., and Gunasekar, S. (2018). Basic Econometrics. Fifth Edition. McGraw-Hill.

Hong, H., \& Stein, J. C. (2007). Disagreement and the Stock Market. Journal of Economic Perspectives, 21(2), 109-128. https://doi.org/10.1257/jep.21.2.109

Infovesta. (2017). Tahun 2017 dan Saham IPO. Retrieved from https://www.infovesta.com/index/article/arti cleread;jsessionid=C44EA47C219A32EF9 DB89C879E109455.NGXA/7c7c48ec7098-4b56-b396-0bcd08a6d508

Isfaatun, E., \& Hatta, A. J. (2010). Analisis Informasi Penentu Harga Saham Saat Initial Public Offering. Jurnal Ekonomi Bisnis, 15(1), 66-74.

Karpoff, J. M. (1986). A theory of trading volume. The Journal of Finance, 41(5), 1069-1087. https://doi.org/10.1111/j.15406261.1986.tb02531.x

Khairunizam, \& Isbanah, Y. (2019). Pengaruh Financial Literacy dan Behavioral Finance Factors Terhadap Keputusan Investasi (Studi Terhadap Investor Saham Syariah Pada Galeri Investasi Syariah UIN Sunan Ampel Surabaya). Jurnal Ilmu Manajemen Fakultas Ekonomi Universitas Negeri Surabaya, 7(2), 516-528.

Low, S. W., \& Yong, O. (2013). Initial public offering and investor heterogeneity: evidence from Malaysia. American Journal of Finance and Accounting, 3(1), 4156.https://doi.org/10.1504/ajfa.2013.057176

Merton, R. C. (1987). A simple model of capital market equilibrium with incomplete information. The Journal of Finance, 42(3), 483-510. https://doi.org/10.1111/j.15406261.1987.tb04565.x
Miller, E. M. (1977). Risk, uncertainty, and divergence of opinion. The Journal of Finance, 32(4), 1151-1168. https://doi.org/10.1111/j.15406261.1977.tb03317.x

Narayanasamy, C., Rashid, M., \& Ibrahim, I. (2018). Divergence of opinion and moderating effect of investors' attentions in IPO market. Review of Behavioral Finance, 10(1), 105-126. https://doi.org/10.1108/RBF-09-2016-0055

Oliveira, A. (2019). Google search-based sentiment indexes. IIMB Management Review, 1, 1-37. https://doi.org/10.1016/j.iimb.2019.10.015

Paramita, R. S., Isbanah, Y., Kusumaningrum, T. M., Musdholifah, \& Hartono, U. (2018). Young investor behavior: implementation theory of planned behavior. International Journal of Civil Engineering and Technology, 9(7), 733-746.

Peng, L., \& Xiong, W. (2006). Investor attention, overconfidence and category learning. Journal of Financial Economics, 80(3) 563-602. https://doi.org/10.1016/j.jfineco.2005.05.00 3

Pompian, M. M. (2006). Behavioral Finance and Wealth Management. USA: John Wiley \& Sons.

Pradhana, R. W. (2018). Pengaruh Financial Literacy, Cognitive Bias, dan Emotional Bias Terhadap Keputusan Investasi (Studi Pada Investor Galeri Investasi Universitas Negeri Surbaya). Jurnal Ilmu Manajemen, 6(4), 108-117.

Ricciardi, V., \& Simon, H. K. (2015). What is behavioral finance. Business, Education and Technology Journal, 2(2), 1-9.

Rock, K. (1986). Why new issues are underpriced. Journal of Financial Economics, 15(1-2), 187-212.

https://doi.org/10.1016/0304405X(86)90054-1

Siegel, R. S., \& Yacht, C. (2009). Behavioral finance and market behavior. In Personal Finance (pp. 393-420). Saylor Foundation.

Wang, H., \& Liu, X. (2014). The impact of investor heterogeneity in beliefs on share repurchase. International Journal of 
Econometrics and Financial Management, 2(3), 102-113.

Wijayanthi, I. M. (2015). Studi Deskriptif: Perilaku Investor Saham di Surabaya Berdasarkan Aspek Psikologis, Demografis dan Rasionalitas. Jurnal Ilmiah Mahasiswa Universitas Surabaya, 4(2), 1-17.
Yüksel, A., \& Yüksel, A. (2006). The link between IPO underpricing and trading volume: evidence from the Istanbul stock exchange. The Journal of Entrepreneurial Finance \& Business Ventures, 11(3), 57-78. 